\title{
ПОСУХОСТІЙКІСТЬ ПЕРСИКА В УМОВАХ ПІВДЕННОГО БЕРЕГА КРИМУ
}

I. Бунчук

Нікітський ботанічний сад - Національний науковий центр НААН

Наведено результати вивчення посухостійкості сортів і форм персика в умовах Південного берега Криму. Для встановлення ступеню посухостійкості використовували показники стійкості до в'янення, відновлення тургору, водний дефіцит і в польових умовах візуально визначали бал посухостійкості. За комплексом ознак виділено форми 1123-89 і 14-93.

Посухостійкість, в'янення, зневоднення, водний дефіцит, сорт, форма

Персик за своїм походженням $є$ рослиною гірських районів північного і центрального районів Китаю [1]. Відрізняючись великою пластичністю, він посів провідне місце як основна кісточкова промислова культура півдня України, зокрема в Криму.

Однією з основних причин невисокої продуктивності та передчасного випаду плодових рослин в посушливих областях півдня України $є$ недостатня стійкість до посухи. Під час селекційної роботи, а також за первинного сортовипробування нових сортів і форм персика необхідно враховувати ступінь посухостійкості. Згідно з визначенням Генкеля, посухостійкість - це властивість рослин, яка виникає в процесі еволюції внаслідок пристосування рослин до несприятливих умов навколишнього середовища [2].

Для підвищення стійкості плодових рослин в світі положень І. В. Мiчуріна (1948) велике значення має виявлення та введення в культуру таких екологічних форм плодових рослин, формування яких відбувалося і відбувається в посушливих умовах. В основі високої посухостійкості лежить здатність тканин переносити без шкоди глибоке зневоднення та тривале в'янення, затримувати воду в тканинах вище рівня летального зневоднення, а також перегрівання [3].

За характером дії на рослини розрізняють грунтову і атмосферну посухи. Дія грунтової посухи в першу чергу позначається на коренях, що поглинають вологу, вони зупиняються в рості і набувають червоно-бурого забарвлення. Це порушує водний баланс, що призводить до в'янення, всихання та обпадання листків. При цьому ріст пагонів, листків, плодів призупиняється, значна частина плодів обпадає. За атмосферної посухи спостерігаєть- 
ся всихання країв або навіть цілих листків. Інколи сухе повітря в поєднанні 3 підвищеною температурою викликає на листках плями запалу - темнобурі чи світло-бурі ділянки тканин з пошкодженими клітинами. За повітряної посухи в першу чергу пошкоджуються молоді верхні листки. Ступінь пошкодження сонячними опіками посилюється при змочуванні їх дощем. Характерною ознакою пошкодження листків плодових дерев високими температурами є в'ялість листків, а інколи і червонуватий відтінок [4].

При доборі форм і сортів для селекції та промисловості представляють інтерес виділені генотипи за попередньою оцінкою водозатримної здатності. Водозатримна здатність являє собою зв'язану вологу, що залишається після зневоднення і втрати вільної води з клітин [5 - 6].

Протидія посусі здійснюється за рахунок добре розвиненої судинної системи, що пояснюється в першу чергу генетикою організму, фізіологобіохімічними та анатомічними особливостями надземних органів. При цьому спостерігається зниження до мінімуму витрат вологи на транспірацію та підвищеною жаростійкістю тканин, а отже, і високою посухостійкістю організму в цілому.

Мета роботи - вивчити ступінь посухостійкості нових селекційних форм і сортів персика в умовах Південного берега Криму у порівнянні 3 існуючими сортами, внесеними в Реєстр сортів рослин - Пушистий Ранній, Кримський Фейєрверк, придатними для поширення в даній зоні. Виділити найбільш посухостійкі для використання в селекції як джерела вихідної ознаки і впровадження в промисловість.

Матеріали і методика досліджень. Дослідження проводились 3 червня по вересень 2011-2012 років в умовах Південного берега Криму на колекційно-селекційній ділянці персика та в лабораторії південних плодових культур Нікітського ботанічного саду (НБС). Об'єктами досліджень були форми і сорти персика, підщепа - мигдаль. Для встановлення ступеня посухостійкості вивчали такі показники, як водозатримна здатність під час в'янення, відновлення тургору та ранковий дефіцит води в листках. Оцінку посухостійкості проводили лабораторно-польовим методом.

Посухостійкість визначали за в'яненням зрізаних листків згідно з методикою Г. М. Єремєєва [6]. Проби листків відбирали в середині липня і серпня о шостій годині ранку в середній частині крони з середини пагона. Зважували по 10 листків у двох повторностях. Водозатримну здатність враховували в процесі в'янення при періодичних зважуваннях за 4, 8, 12, 24, 36, 48 годин. Коли втрата в масі досягала 30-35 \% початкової сирої маси, листки герметично розміщували між двома шарами вологого фільтрувального паперу на 24 години. Після цього встановлювали ступінь відновлення тургору за відсотком листкової поверхні, що не мала бурих і темно-коричневих плям відмерлої тканини. Ранковий дефіцит вологи визначали шляхом взяття проб і занурення черешків листків у воду на добу; перерахунок зроблений у відсотках до сирої маси. 
Оцінку дерев за посухостійкістю в польових умовах проводили окомірно 3 липня по серпень. Бал посухостійкості визначали за 10-бальною шкалою [7-8].

Результати досліджень. Отримання високих і стійких врожаїв визначається впливом метеорологічних умов. Клімат Південного берега Криму характеризується жарким літом і довготривалим посушливим періодом 3 травня по вересень. Несприятливі умови - критичне підвищення температури повітря, недостатня кількість опадів - призводять до того, що врожайність зменшується в декілька разів.

Аналіз метеорологічних умов свідчить про підвищення середньомісячних показників у літні місяці та істотне зменшення опадів. Так, у липні 2011-2012 років середня температура склала $24,8{ }^{\circ} \mathrm{C}$ i $26,4^{\circ} \mathrm{C}$, що на $2{ }^{\circ} \mathrm{C}$ i $3,6{ }^{\circ} \mathrm{C}$ вище норми відповідно; в серпні $-23,6{ }^{\circ} \mathrm{C}$, що на $1{ }^{\circ} \mathrm{C}$ вище норми; у вересні - 20,3, що на $1,9^{\circ} \mathrm{C}$ вище норми.

Запаси продуктивної вологи в метровому шарі грунту склали в липні 2011-2012 років 10 мм (6 \% НB) і 5 мм (3\% НВ) відповідно. В серпні та вересні вологість грунту була 0 мм $(0 \%$ HB). Такі погодні умови сприяли виявленню ознак стійкості рослин до посухи.

Персик в порівнянні з іншими плодовими культурами - сливою, аличею, абрикосом - є найбільш посухостійкою рослиною. У сухий період листя персика відрізняється більшим вмістом води, а віддача води йде менш інтенсивно, чим і характеризується форма 1123-89 у порівнянні з Пушистим Раннім, Кримським Фейєрверком. Здатність листя відновлювати тургор i зелене забарвлення після в'янення перебувають у прямій залежності від ступеня їх зневоднення.

Водозатримна здатність різних органів рослин відображає їх пристосованість до несприятливих умов навколишнього середовища. Що більше необхідно часу для втрати 30-35 \% вологи від початкової маси, то більше міститься глибоко зв'язаної води. Це свідчить про потенційну здатність переносити глибоке в'янення, а здатність відновлювати тургор листків після такого в'янення - про можливість без істотних змін поновлювати фізіологічні процеси в тканинах листків.

Визначення водозатримної здатності під час в'янення свідчить про коливання цього показника. Процес в'янення в лабораторних умовах тривав 48 годин для всіх відібраних зразків, і тільки дикий представник - персик миру -вже за 24 години втратив понад 30 \% вологи. Гібриди з ним - Персімира 99-87, Персімира 295-86 - характеризуються більшою водозатримною властивістю, за той самий час, відповідно, втрата води становила 20,75 \% і 17,28 \% у 2011 році та $12,24 \%$ i 14,45 \% у 2012 році. Мінімальна здатність затримувати вологу спостерігається у персика Давіда Білоквіткового, Давіда 13-8м, Персімира 9987, Персімира 295-86 (рис. 1). Поряд з тим, різко виділяються форми 1123-89, 14-93, 13-93 з максимальним проявом властивості утримувати вологу. Тобто під час скорочення витрат води персик може створювати передумови для виживання в умовах жорсткого дефіциту вологи (табл. 1, 2). 


\section{Віддано \% води в процесі в'янення, через 8, 12, 24,} 36, 48 годин (2011-2012 р.)

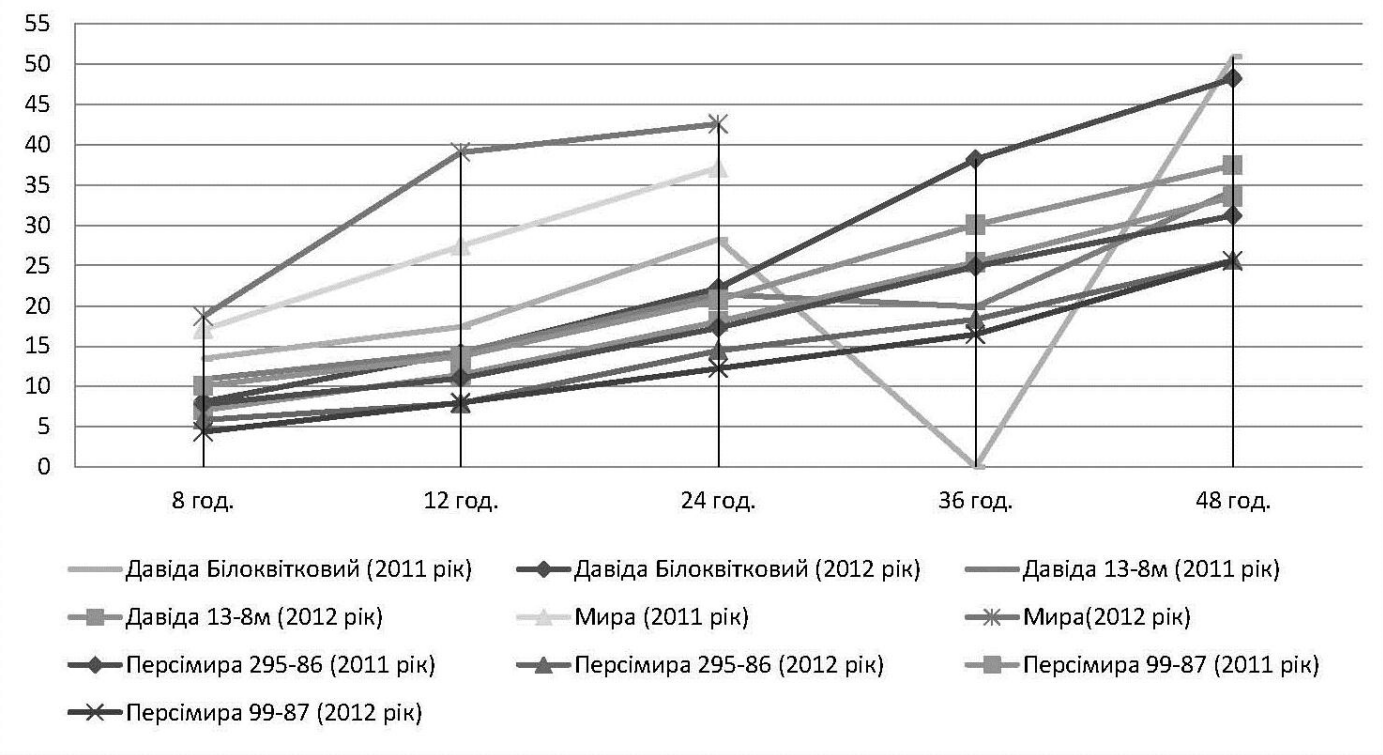

Рис. 1. 
Таблиця 1

Визначення посухостійкості за лабораторно-польовим методом, 2011 p.

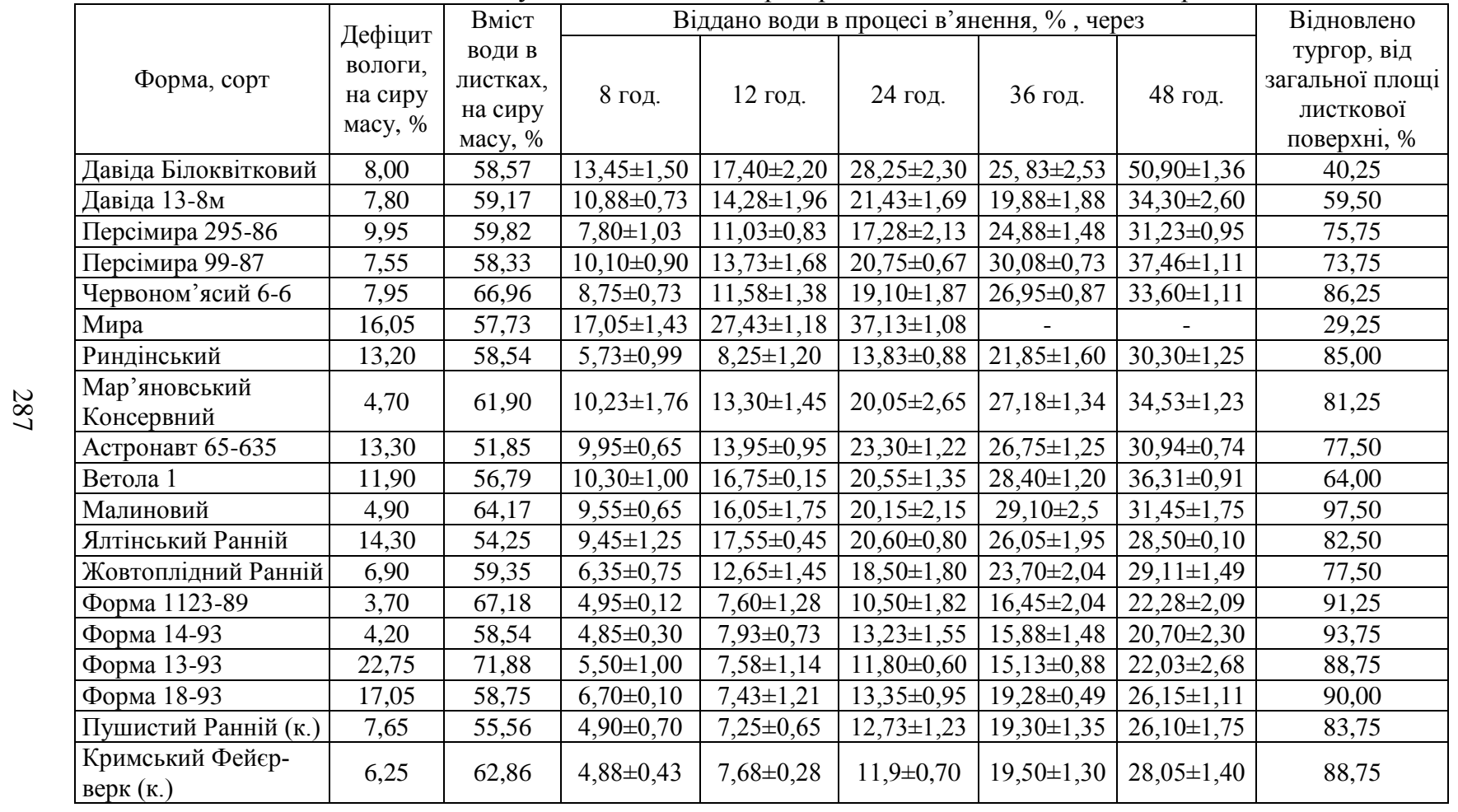


Таблиця 2

Визначення посухостійкості за лабораторно-польовим методом, 2012 р.

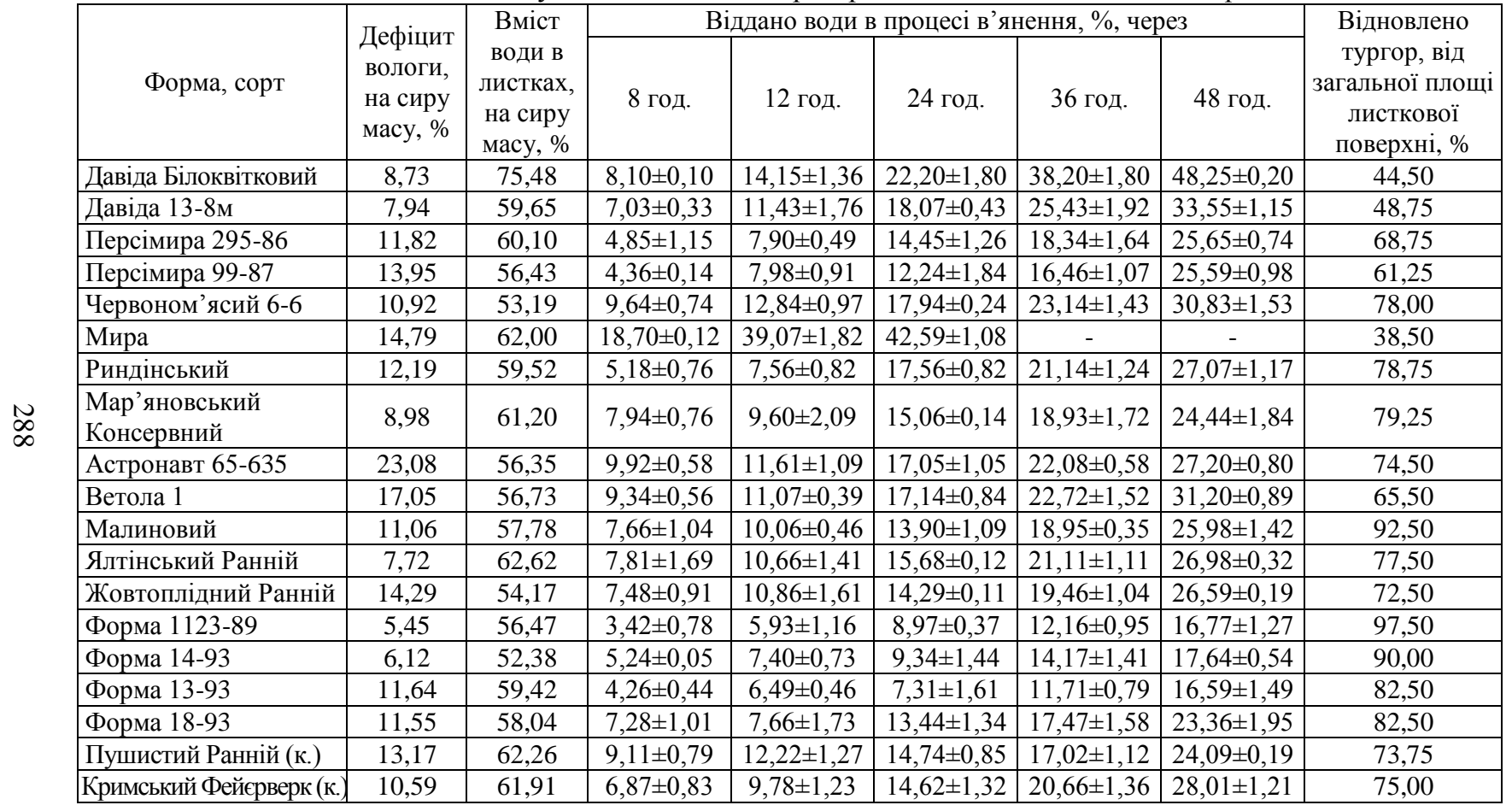


Мінімальний дефіцит вологи, характерний для форм 1123-89 і 14-93, у 2011 р. становить 3,70 \% і 4,20\% до сирої маси листків та в 2012 р. $5,45 \%$ і 6,12 \% відповідно (табл. 1, 2).

Візуальне спостереження за станом надземної частини персика показало, що найбільш посухостійкими є форми 1123-89, 13-89, 14-89, 18-89 і сорти Малиновий, Риндінський. Середньопосухостійкими є сорти Ялтинський Ранній, Жовтоплідний Ранній, Червоном'ясий 6-6, Мар'яновський Консервний. Низькою посухостійкістю відмічені дикий вид персик миру і його гібриди - Персімира 99-87, Персімира 295-86, гібриди з персиком Давіда Давіда Білоквітковий, Давіда 13-8м (табл. 3).

Таблиця 3

Визначення посухостійкості в польових умовах (за 10-бальною шкалою)

\begin{tabular}{|l|c|c|c|}
\hline \multicolumn{1}{|c|}{ Форма, сорт } & $2011 \mathrm{p}$. & $2012 \mathrm{p}$. & середнє \\
\hline Давіда Білоквітковий & 4 & 4 & 4 \\
\hline Давіда 13-8м & 5 & 5 & 5 \\
\hline Персімира 295-86 & 6 & 7 & 6,5 \\
\hline Персімира 99-87 & 7 & 6 & 6,5 \\
\hline Червоном'ясий 6-6 & 8 & 8 & 8 \\
\hline Мира & 3 & 3 & 3 \\
\hline Риндінський & 9 & 8 & 8,5 \\
\hline Мар'яновський Консервний & 8 & 8 & 8 \\
\hline Астронавт 65-635 & 7 & 7 & 7 \\
\hline Ветола 1 & 6 & 6 & 6 \\
\hline Малиновий & 10 & 9 & 9,5 \\
\hline Ялтінський Ранній & 8 & 8 & 8 \\
\hline Жовтоплідний Ранній & 8 & 7 & 7,5 \\
\hline Форма 1123-89 & 9 & 10 & 9,5 \\
\hline Форма 14-93 & 9 & 9 & 9 \\
\hline Форма 13-93 & 9 & 8 & 8,5 \\
\hline Форма 18-93 & 9 & 8 & 8,5 \\
\hline Пушистий Ранній (к.) & 8 & 7 & 7,5 \\
\hline Кримський Фейсрверк (к.) & 8 & 7 & 7,5 \\
\hline
\end{tabular}

Висновок. Персик - культура, що характеризується високою стійкістю до посухи. Високим ступенем посухостійкості в 9 балів відрізняються форми 1123-89, 14-93 і Малиновий. За комплексом ознак - стійкість до в'янення, відновлення тургору, мінімальний водний дефіцит - виділено форми 1123-89 і 14-93. Рекомендуємо використовувати їх в селекції як джерела посухостійкості. 


\section{Список використаних джерел}

1. Витковский В. Л. Персик. / В. Л. Витковский // Плодовые растения мира. - Спб.: Лань, 2003. - С. 139-160.

2. Генкель П. А. Засухоустойчивость и продуктивность растений / П. А. Генкель // С.-х. биология. - М. : Колос, 1979. - Т. 14. - № 3. C. 313-322.

3. Фалькова Т. В. Диагностика засухоустойчивости растений по комплексу признаков / Т. В. Фалькова, М. Г. Гельберт, Г. Н. Шестаченко // Труды Гос. Никит. ботан. сада. - Ялта, 1979. - Т. 78. - С. 5-15.

4. Генкель П. А. Физиология устойчивости и селекция растений / П. А. Генкель // С.-х. биология. - М. : Колос, 1966. - Т. 1. - № 1. - С. 86-93.

5. Волошина $A$. A. Влияние засушливых условий на водный режим косточковых плодовых культур / А. А. Волошина, Г. Н. Еремеев // Бюл. Гос. Никит. ботан. сада. - Ялта, 1976. - Вып. 2(30). - С. 28-34.

6. Еремеев Г. Н. Лабораторно-полевой метод оценки засухоустойчивости плодовых и других растений и результаты его применения / Г. Н. Еремеев // Сб. науч. трудов. -М.: Колос, 1964. - Т. 37. - С. 472-489.

7. Еремеев Г. Н. Методические указания по отбору засухоустойчивых сортов и подвоев плодовых растений / Г. Н. Еремеев, А. И. Лищук // - Ялта, 1974. $-18 \mathrm{c}$.

8. Интенсификация селекции плодовых культур / Под ред. В. К. Смыкова, А. И. Лищука. - Ялта, 1999. - Т. 118. - 216 с. 